\title{
Effect of Air-Frying on the Bioactive Properties of Eggplant (Solanum melongena L.)
}

\author{
Ahmad Mohammad Salamatullah *D, Mohammed Asif Ahmed (D), Mohammed Saeed Alkaltham, Khizar Hayat*, \\ Najla Sulaiman Aloumi, Alhanouf Mohammed Al-Dossari, Laila Naif Al-Harbi and Shaista Arzoo $D^{D}$
}

Department of Food Science \& Nutrition, College of Food and Agricultural Sciences, King Saud University, Riyadh 11451, Saudi Arabia; masifa@ksu.edu.sa (M.A.A.); malkaltham@ksu.edu.sa (M.S.A.); n.aloumi@hotmail.com (N.S.A.); 438203060@student.ksu.edu.sa (A.M.A.-D.); lalharbi1@ksu.edu.sa (L.N.A.-H.); sarzoo@ksu.edu.sa (S.A.)

* Correspondence: asalamh@ksu.edu.sa (A.M.S.); khayat@ksu.edu.sa (K.H.)

Citation: Salamatullah, A.M.; Ahmed, M.A.; Alkaltham, M.S.; Hayat, K.; Aloumi, N.S.; Al-Dossari, A.M.; Al-Harbi, L.N.; Arzoo, S. Effect of Air-Frying on the Bioactive Properties of Eggplant (Solanum melongena L.). Processes 2021, 9, 435. https://doi.org/10.3390/pr9030435

Academic Editor: Zongbi Bao

Received: 4 February 2021

Accepted: 24 February 2021

Published: 28 February 2021

Publisher's Note: MDPI stays neutral with regard to jurisdictional claims in published maps and institutional affiliations.

Copyright: (c) 2021 by the authors. Licensee MDPI, Basel, Switzerland. This article is an open access article distributed under the terms and conditions of the Creative Commons Attribution (CC BY) license (https:// creativecommons.org/licenses/by/ $4.0 /)$.

\begin{abstract}
The eggplant is an important vegetable that is used all over the world and it contains valuable bioactive properties. Cooking methods affect the nutritional value as well as the functional characteristics of vegetables. This study investigated the effect of air-frying at different temperatures and the extraction solvents on the bioactive properties of eggplant. The eggplant air-fried for $25 \mathrm{~min}$ and extracted with $50 \%$ ethanol exhibited the highest total flavonoid content $(35.10 \mathrm{mg}$ catechin equivalent per gram dry weight), while its total polyphenol content was found as $87.81 \mathrm{mg}$ gallic acid equivalent per gram dry weight. The uncooked sample exhibited the lowest DPPH scavenging ( $\mathrm{IC}_{50}: 422.12 \mathrm{mg} / \mathrm{mL}$ reducing power: 0.914$)$, while the highest DPPH scavenging activity $\left(\mathrm{IC}_{50}: 2.87 \mathrm{mg} / \mathrm{mL}\right.$; reducing power: 0.936$)$ was recorded for the sample air-fried for $25 \mathrm{~min}$ and extracted with $50 \%$ ethanol. The highest amount of tannic acid was found in medium-cooked eggplant, while chlorogenic acid was the highest in the high-cooked sample. These results might be helpful for functional food processors.
\end{abstract}

Keywords: eggplant; air-fry; cooking method; phenolic compounds

\section{Introduction}

Eggplant (Solanum melongena L.) is a very notable crop that is consumed globally. It is widely cultivated in tropical and subtropical areas of the world [1]. In 2018, its world production was around 54.07 million tons [2]. China is the leading producer of eggplant, followed by India, Egypt, Turkey, and Iran [1]. Its caloric value is quite low [3], and it is known for its high content of minerals, vitamins (Table 1), and phytochemicals such as flavonoids and phenolics that possess high antioxidant activity [4,5]. Most parts of the eggplant, such as the pulp, peel, leaf, calyx, and stem, possess antioxidant activity and are rich in phenolic compounds [4]. Its bioactive properties are mostly related to its phenolic compounds, particularly chlorogenic acid, which is the most abundant polyphenol in the fruit flesh, accounting for $70 \%$ to $90 \%$ of all of the polyphenol contents [6,7] and anthocyanins in the fruit skin [8]. A negative correlation between the consumption of phytochemicals and chronic diseases has been reported in various studies $[9,10]$.

Processing is a prerequisite for most foods in order to enhance the metabolism and digestion in the human digestive system [11]. However, numerous alterations in the physical characteristics of foods, such as appearance, sensory properties, as well as chemical composition, occur during processing $[12,13]$. Studies have reported an upsurge in the concentration of polyphenols and flavonoids and have shown certain stability at high temperatures [14,15]. Miglio et al. [16] reported increases in Trolox equivalent antioxidant capacity, ferric reducing antioxidant power, and total radical antioxidant parameter with different degrees of grilling of eggplants. 
Table 1. Nutritional components of eggplant [17].

\begin{tabular}{|c|c|c|}
\hline Nutrient & Unit & Value Per $100 \mathrm{~g}$ \\
\hline \multicolumn{3}{|l|}{ Main components } \\
\hline Energy & $\mathrm{kJ}$ & 100 \\
\hline Total carbohydrates & G & 5.88 \\
\hline Sugars & G & 3.53 \\
\hline Protein & G & 0.98 \\
\hline Fiber & G & 3.00 \\
\hline Lipid & G & 0.18 \\
\hline Water & G & 92.3 \\
\hline \multicolumn{3}{|l|}{ Minerals } \\
\hline Calcium & $\mathrm{mg}$ & 9.00 \\
\hline Iron & $\mathrm{mg}$ & 0.23 \\
\hline Sodium & $\mathrm{mg}$ & 2.00 \\
\hline Potassium & $\mathrm{mg}$ & 229.0 \\
\hline Magnesium & $\mathrm{mg}$ & 14.0 \\
\hline Phosphorus & $\mathrm{mg}$ & 24.0 \\
\hline Zinc & $\mathrm{mg}$ & 0.16 \\
\hline \multicolumn{3}{|l|}{ Vitamins } \\
\hline Vitamin C & $\mathrm{mg}$ & 2.20 \\
\hline Thiamin & $\mathrm{mg}$ & 0.039 \\
\hline Niacin & $\mathrm{mg}$ & 0.649 \\
\hline Riboflavin & $\mathrm{mg}$ & 0.037 \\
\hline Folate & $\mu g$ & 22.0 \\
\hline Vitamin B6 & $\mathrm{mg}$ & 0.084 \\
\hline Vitamin A, RAE * & $\mu \mathrm{g}$ & 1.00 \\
\hline Vitamin E ( $\alpha$-tocopherol) & $\mathrm{mg}$ & 0.30 \\
\hline Vitamin K (phylloquinone) & $\mu \mathrm{g}$ & 3.50 \\
\hline \multicolumn{3}{|l|}{ Lipids } \\
\hline Fatty acids, total saturated & G & 0.034 \\
\hline Fatty acids, total monosaturated & G & 0.016 \\
\hline Fatty acids, total polysaturated & $\mathrm{g}$ & 0.076 \\
\hline
\end{tabular}

* RAE: Retinol Activity Equivalents.

Eggplant is a rich source of nutrients (Table 1) and is usually consumed after boiling in water, grilling, or frying [18]. Frying reflects a dehydration process in which a simultaneous heat and mass transfer happens [19]. Various factors such as moisture content of food, frying time, and types of batter used for frying affect the quantity of oil absorbed by food [20]. Various diseases, such as diabetes, obesity, cardiovascular disease, hypertension, and cancer, have been found to be associated with higher consumption of fried food [21,22]. The current trends in population demographics and socio-economic changes, such as the desire for enhanced quality of life as well as the growing costs of health care, have been the driving force for the food industry to produce low-fat and fat-free products without affecting the sensory qualities. Many techniques such as low pressure microwave application and different pretreatments have been projected to reduce the oil content in fried foodstuffs.

The air-frying method of cooking is an alternative to conventional means of frying foods that employs the circulation of heated air by rapid air technology. It involves the direct interaction between the food product, which used to be continuously in motion to endorse homogeneous contact between both phases, and a diffusion of oil droplets in hot 
air in a frying chamber [23]. The hot air movement cooks food item from inside, and the typical crust of fried products gradually appears outside [24]. Therefore, the present study was undertaken to investigate the effects of different cooking times of eggplant at $150{ }^{\circ} \mathrm{C}$ via air-frying on its total polyphenol content, total flavonoid content, and antioxidant activity in terms of DPPH (2, 2-diphenyl-1-picryl-hydrazyl) and reducing power.

\section{Materials and Methods}

\subsection{Microwave Cooking and Sample Preparation}

Black eggplants were procured from a local market in Riyadh, Saudi Arabia. The whole eggplant was cut into uniform pieces of $1 \mathrm{~cm}$ thickness and placed in the household air-fryer (Philips Avance Collection 1.4 Kg Airfryer XXL. Model No: HD9650/94. Made in Turkey). The heating of the eggplant was performed at $150{ }^{\circ} \mathrm{C}$ for $5 \mathrm{~min}, 15 \mathrm{~min}$, and $25 \mathrm{~min}$ where were termed as low-cooked (LC), medium-cooked (MC), and high-cooked (HC), respectively (Figure 1). After cooking, the samples were cooled to room temperature $\left(23^{\circ} \mathrm{C}\right)$ and then were placed in an oven dryer at $40^{\circ} \mathrm{C}$ for $72 \mathrm{~h}$. Uncooked eggplant was dried under the same conditions and was used as a control. The dried samples were ground into powder, sieved through 60 mesh, and stored in air-tight plastic bags at room temperature for further use.

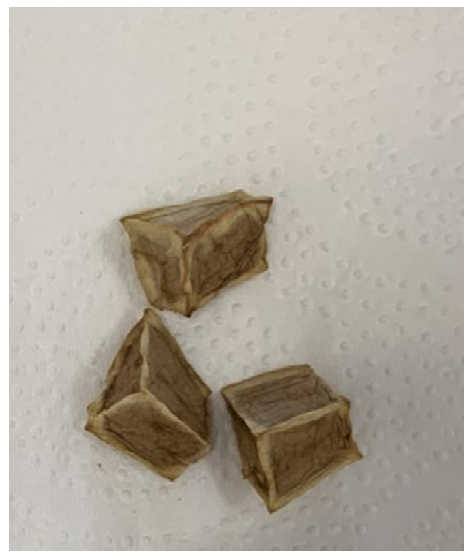

(a)

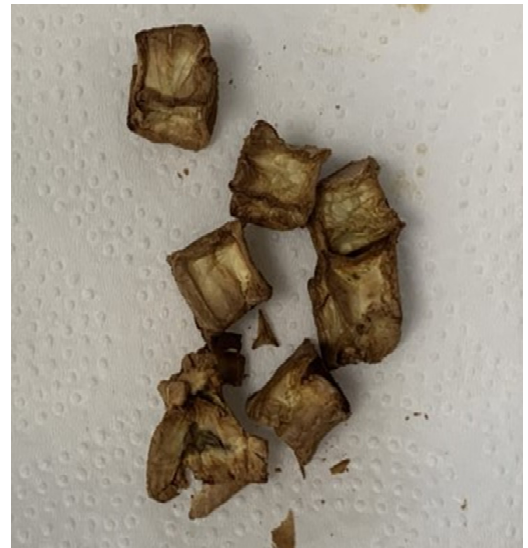

(b)

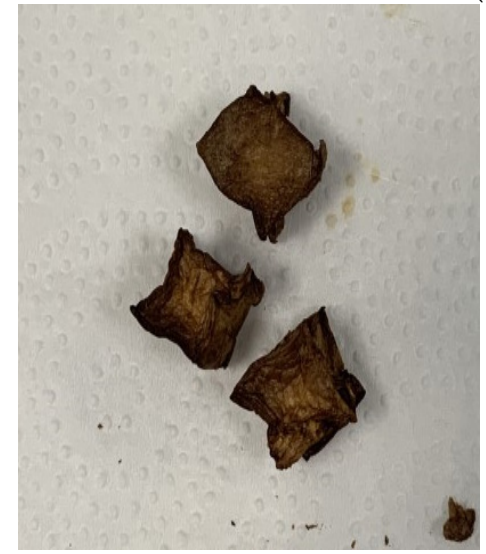

(c)

Figure 1. Eggplant samples air-fried at $150{ }^{\circ} \mathrm{C}$ for $5 \mathrm{~min}(\mathbf{a}), 15 \mathrm{~min}(\mathbf{b})$, and $25 \mathrm{~min}$ (c).

\subsection{Extraction}

The eggplant sample ( $2 \mathrm{~g})$ was extracted with different concentrations of ethanol $(20 \mathrm{~mL})$, such as $100 \%$ ethanol, $50 \%(\mathrm{v} / \mathrm{v})$ ethanol, and $25 \%(\mathrm{v} / \mathrm{v})$ ethanol, employing ultrasound extractions for $1 \mathrm{~h}$ at $23{ }^{\circ} \mathrm{C}$. The mixture was then centrifuged at $3000 \times g$ for $10 \mathrm{~min}$ at room temperature. The supernatant was then filtered using a Whatman filter 
paper number 2. The extract was stored at $4{ }^{\circ} \mathrm{C}$ for further analysis. For HPLC analysis of phenolic compounds, the samples were extracted with $100 \%$ ethanol.

\subsection{Total Polyphenol Content}

Folin-Ciocalteu (FC) reagent was used to determine the total polyphenol content (TPC) according to the procedure described by Hayat [25]. Briefly, $125 \mu \mathrm{L}$ of FC was added to $25 \mu \mathrm{L}$ of extract containing $1500 \mu \mathrm{L}$ of nanopure water and the mixture was allowed to stand for $30 \mathrm{~min}$. Subsequently, with the addition of $375 \mu \mathrm{L}$ of $20 \% \mathrm{Na}_{2} \mathrm{CO}_{3}$, the final volume of the mixture was made up to $2500 \mu \mathrm{L}$. After $30 \mathrm{~min}$ of incubation at room temperature, the absorbance was noted at $760 \mathrm{~nm}$. Gallic acid was used at different concentrations to construct the calibration curve. The results were calculated as gallic acid equivalent per gram dry weight of the sample (mg GAE/g DW).

\subsection{Total Flavonoid Content}

The total flavonoid content (TFC) was determined as described previously [25]. The extract $(250 \mu \mathrm{L})$ was mixed with water $(1000 \mu \mathrm{L})$ and $75 \mu \mathrm{L}$ each of $\mathrm{NaNO}_{2}$ and $\mathrm{AlCl}_{3}$ and then incubated at room temperature. After $5 \mathrm{~min}$ of incubation, $600 \mu \mathrm{L}$ of water and 500 $\mu \mathrm{L}$ of $1 \mathrm{M} \mathrm{NaOH}$ were added and the absorbance was measured at $510 \mathrm{~nm}$. The results were given as catechin equivalent per gram dry weight of the sample (mg CE/g DW)

\subsection{DPPH Scavenging}

To determine the free radical scavenging capacity of the extract, a DPPH assay was used as described earlier, with some modifications [26]. The reaction mixture contained $130 \mu \mathrm{L}$ of aliquot of the extract and $0.1 \mathrm{mM}$ DPPH solution $(2 \mathrm{~mL})$. Following incubation for $30 \mathrm{~min}$ in the dark, the absorbance of the reaction mixtures was read at $510 \mathrm{~nm}$. The control was prepared by ethanol instead of extract and the percentage of DPPH radical scavenging activity was calculated as follows:

$$
\mathrm{DPPH} \text { scavenging } \%=\mathrm{A}_{\text {control }}-\mathrm{A}_{\text {sample }} / \mathrm{A}_{\text {control }} \times 100
$$

The sample was tested at different concentrations to determine the $50 \%$ inhibitory concentration $\left(\mathrm{IC}_{50}\right)$ value, which was calculated by plotting the sample concentration along the $\mathrm{X}$-axis and the inhibition percentage on the Y-axis.

\subsection{Reducing Power}

The reducing power was estimated according to the method used by Sharma and Vig with some modifications [27]. Briefly, the extract $(0.5 \mathrm{~mL})$ was mixed with $1.25 \mathrm{~mL}$ buffer $(0.2 \mathrm{M}, \mathrm{pH} 6.6)$ and $1.25 \mathrm{~mL}$ of potassium ferricyanide and then incubated at $50{ }^{\circ} \mathrm{C}$ for $20 \mathrm{~min}$. Next, trichloroacetic acid $(1.25 \mathrm{~mL})$ was added and the centrifugation was performed for $10 \mathrm{~min}$ at $3000 \times \mathrm{g}$. Lastly, an aliquot $(1.25 \mathrm{~mL})$ was acquired from the supernatant, to which $1.25 \mathrm{~mL}$ of water and $0.25 \mathrm{~mL}$ of ferric chloride were added and the absorbance was measured at $700 \mathrm{~nm}$.

\subsection{HPLC Analysis of Phenolic Compounds}

The presence of phenolic compounds (tannic acid, resorcinol, chlorogenic acid, caffeic acid, vanillin, acetyl salicylic acid) in eggplant samples was carried out using HPLC analysis, as described earlier with some modifications [28]. The prominence HPLC system Shimadzu (Kyoto, Japan) was equipped with an LC-20AB binary pump and variable Shimadzu SPD-10A UV detector. The Zorbax SB-C18 column $(250 \times 4.6 \mathrm{~mm}, 5 \mu \mathrm{m}$; Agilent, Santa Clara, CA, USA), mobile-phase Milli Q water (1\% acetic acid, A), and $\mathrm{MeOH}$ (B) were used. The binary gradient program used was $0-10 \mathrm{~min} 15-30 \% \mathrm{~B} ; 10-20 \mathrm{~min}$ $30-40 \%$ B; $20-30 \min 40-50 \%$ B; 30-41 $\min 50-60 \%$ B; and $41-45 \min 15 \%$ B. The flow rate was $1.0 \mathrm{~mL} / \mathrm{min}$. The injection volume was $10 \mu \mathrm{L}$, and the detector was set at $280 \mathrm{~nm}$. Compounds in eggplant samples were identified by comparing their peak retention time with those of standards. All samples were analyzed in duplicate. 


\subsection{Statistical Analysis}

One-way analysis of variance (ANOVA) was performed by SAS (Version 9.2, 2000-2008; SAS Institute Inc., Cary, NC, USA) at a significance level of $p \leq 0.05$ to identify the differences among the treatment groups. If significant differences were found, a post-hoc analysis using Duncan's multiple range test was performed at a confidence interval of $95 \%$. All analyses otherwise stated were performed in triplicate and the standard deviations were evaluated.

\section{Results and Discussion}

\subsection{Effect of Air-Frying and Extraction Solvents on the Total Polyphenol Content of Eggplant}

Figure 2 shows the total polyphenol content (TPC) of eggplant air-fried for different times and extracted with different solvents. The high-cooked sample air-fried for $25 \mathrm{~min}$ and extracted with $25 \%$ ethanol (v/v) (HC25) gave the highest TPC. The eggplant airfried for $25 \mathrm{~min}$ and extracted with 50\% ethanol (HC50) ranked second in terms of its total polyphenol content, and it was followed by the samples air-fried for $15 \mathrm{~min}$ and extracted with 50\% ethanol (MC50) and 25\% ethanol (MC25). The TPCs of all of these eggplant samples were significantly dissimilar from each other $(p<0.05)$. The eggplant extracted with absolute ethanol showed the significantly lowest level of TPC amongst all of the other treatments. For example, the TPC of low-cooked eggplant extracted with absolute ethanol (LC100), 50\% ethanol (LC50), and 25\% ethanol (LC25) was 3.94, 10.48, and $26.18 \mathrm{mg}$ GAE/g dry weight, respectively. Moreover, the TPC of the control (untreated) sample was significantly lower than all of the other samples, which showed that air-frying helped to increase the total polyphenol content of eggplant. Many studies have reported an increase in the total phenolic content upon heating or roasting of the plant samples, which could be ascribed to the release of bioactive compounds from their conjugates [29,30]. Das et al. [31] reported a higher total polyphenol content in grilled eggplant as compared to a raw sample. There was an increase in the total polyphenol content of deep-fried eggplant as compared to the raw fruits. Lo Scalzo et al. [32] reported increased polyphenolic content in grilled eggplant slices. Another study also reported the increased total polyphenol content of deep-fried eggplant [33].

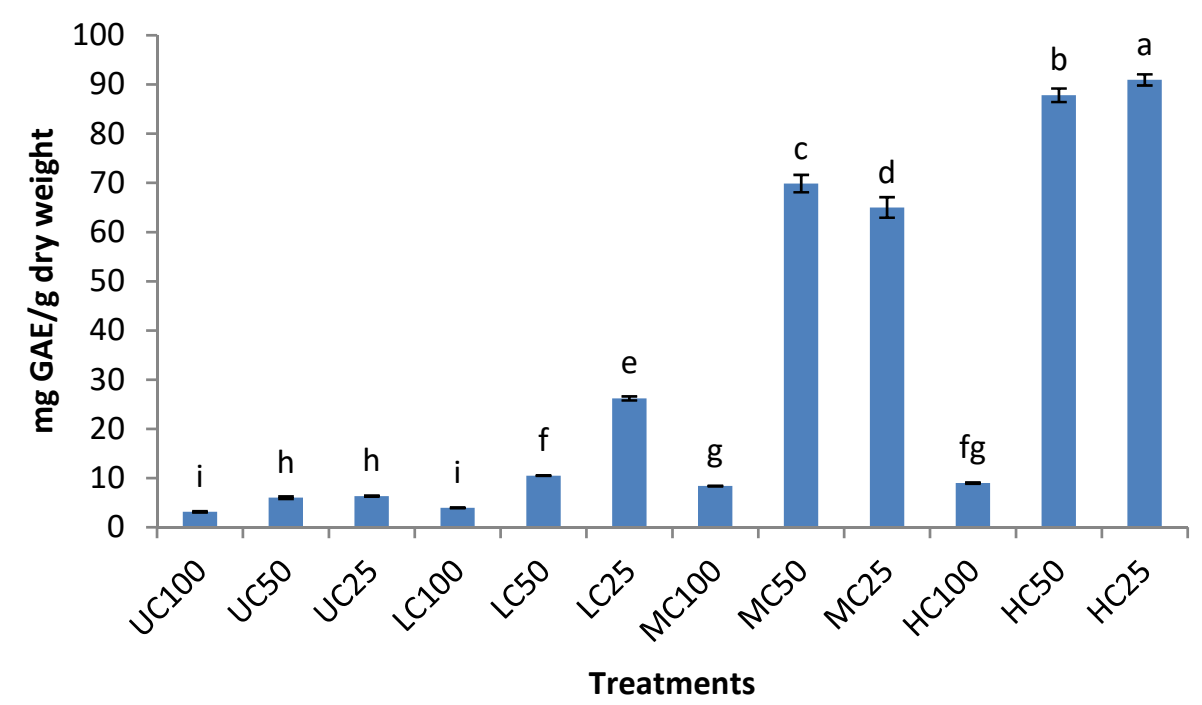

Figure 2. Total polyphenol content of air-fried eggplant. The treatment codes consisting of different letters and digits represent the uncooked (UC), high-cooked (HC), medium-cooked (MC), and lowcooked (LC) eggplant samples extracted with absolute ethanol (100), 50\% ethanol (50), and 25\% ethanol (25). The bars containing different letters are significantly different from each other $(p<0.05)$. GAE: gallic acid equivalent. 


\subsection{Effect of Air-Frying and Extraction Solvents on the Total Flavonoid Content of Eggplant}

The total flavonoid content (TFC) of eggplant as affected by air-frying and extraction solvent is shown in Figure 3. It can be seen that the TFC was greatly influenced by the air-frying time and the extraction solvents. The eggplant air-field for $25 \mathrm{~min}$ and extracted with 50\% ethanol (HC50) exhibited the highest TFC ( $35.10 \mathrm{mg}$ catechin equivalent per gram dry weight), followed by the sample air-fried for $15 \mathrm{~min}$ and extracted with $50 \%$ ethanol (MC50) (31.75), air-fried for 25 min and extracted with 25\% ethanol (HC25) (28.30), and air-fried for $15 \mathrm{~min}$ and extracted with 25\% ethanol (MC25) (18.75). Similar to our findings, a previous study reported that the TFC of both conventionally and organically grown eggplant fruits was increased during their steam processing [34]. On the contrary, ArkoubDjermoune et al. [14] reported that flavonol content increased but flavonoids decreased in fried, grilled, and baked eggplant fruits as compared to fresh eggplants. Similar to the TPC, the TFC of the control sample and the samples extracted with absolute ethanol were significantly lower $(p<0.05)$ than all of the other samples. Among other solvents, the $50 \%$ ethanol showed better extraction of eggplant total flavonoids. The solubility of the phenolic compounds depends on the polarity of the extraction solvent. Several studies have showed that the recovery of phenolic acids increased using ethanol and water as cosolvents due to the enhancement of solvent polarity [35-37].

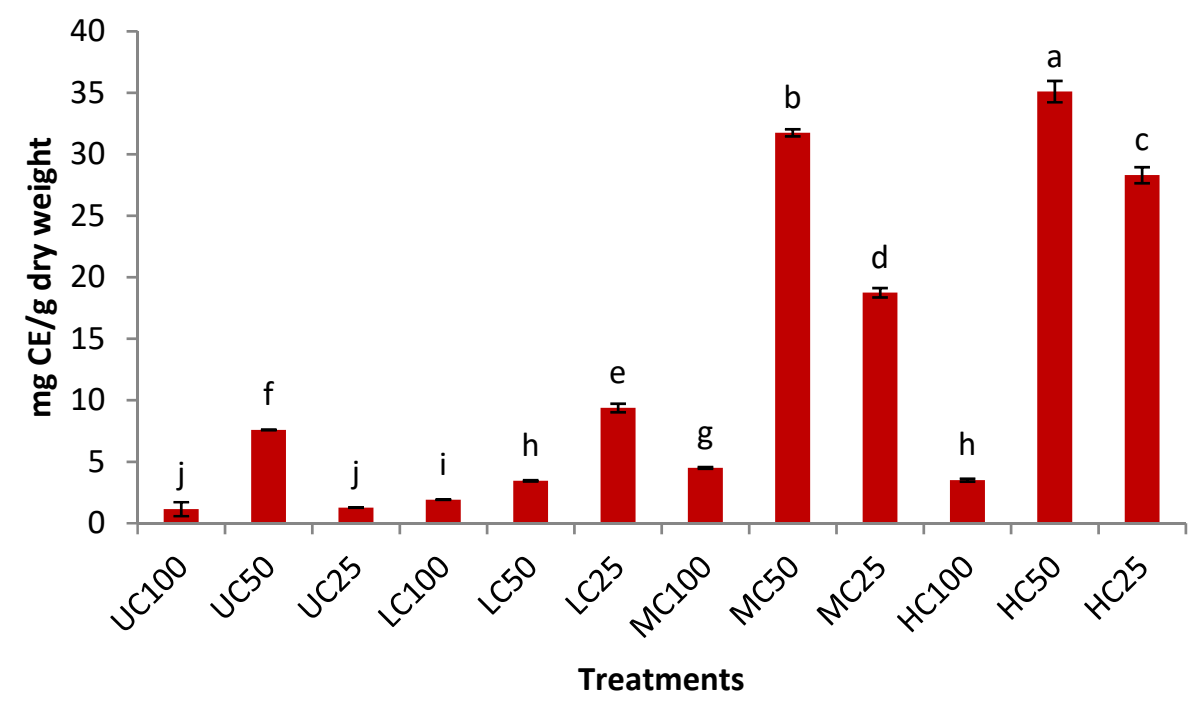

Figure 3. Total flavonoid content of air-fried eggplant. The treatment codes consisting of different letters and digits represent the uncooked (UC), high-cooked (HC), medium-cooked (MC), and lowcooked (LC) eggplant samples extracted with absolute ethanol (100), 50\% ethanol (50), and 25\% ethanol (25). The bars containing different letters are significantly different from each other $(p<0.05)$. $\mathrm{CE}$ : catechin equivalent.

\subsection{Effect of Air-Frying and Extraction Solvents on the DPPH Scavenging of Eggplant}

The effect of air-frying and extraction solvents on the 2,2-diphenyl, 1-picrylhyrdazyl (DPPH) radical scavenging of eggplant is shown in Figure 4. The DPPH scavenging potential of the eggplant was expressed as its $50 \%$ inhibitory concentration $\left(\mathrm{IC}_{50}\right)$. The lower the $\mathrm{IC}_{50}$, the higher the scavenging potential. As can be seen in Figure 3, the lowest $\mathrm{IC}_{50}(2.87 \mathrm{mg} / \mathrm{mL})$ was recorded for the high-cooked sample that was extracted with $50 \%$ ethanol (HC50). The $\mathrm{IC}_{50}$ values of the high-cooked sample extracted with $25 \%$ ethanol (HC25) and the medium-cooked extracted with 50\% (MC50) and 25\% (MC25) ethanol were 3.16, 3.74, and $4.19 \mathrm{mg} / \mathrm{mL}$, respectively. The uncooked sample exhibited the highest IC50, showing that it had the lowest DPPH scavenging among all of the other samples. In a previous study, the DPPH radical scavenging capability of the eggplant fruit was increased upon boiling, steaming, or microwaving compared with the untreated sample [38]. Uthumporn et al. [39] investigated the effect of various cooking procedures 
on the nutritional value of eggplant, and he found the DPPH scavenging potential in the following order: control < frying < grilling < superheated steam method. All the heating procedures applied to onion, green pepper, and cardoon led to an increase in DPPH radical scavenging potential of these vegetables [40]. The increase in antioxidant capacity might be due to the isomerization and hydrolysis of phenolic compounds; as additionally, the Maillard reaction products possessing antioxidant potential may contribute towards the increased antioxidant potential of the heated food products $[14,41]$.

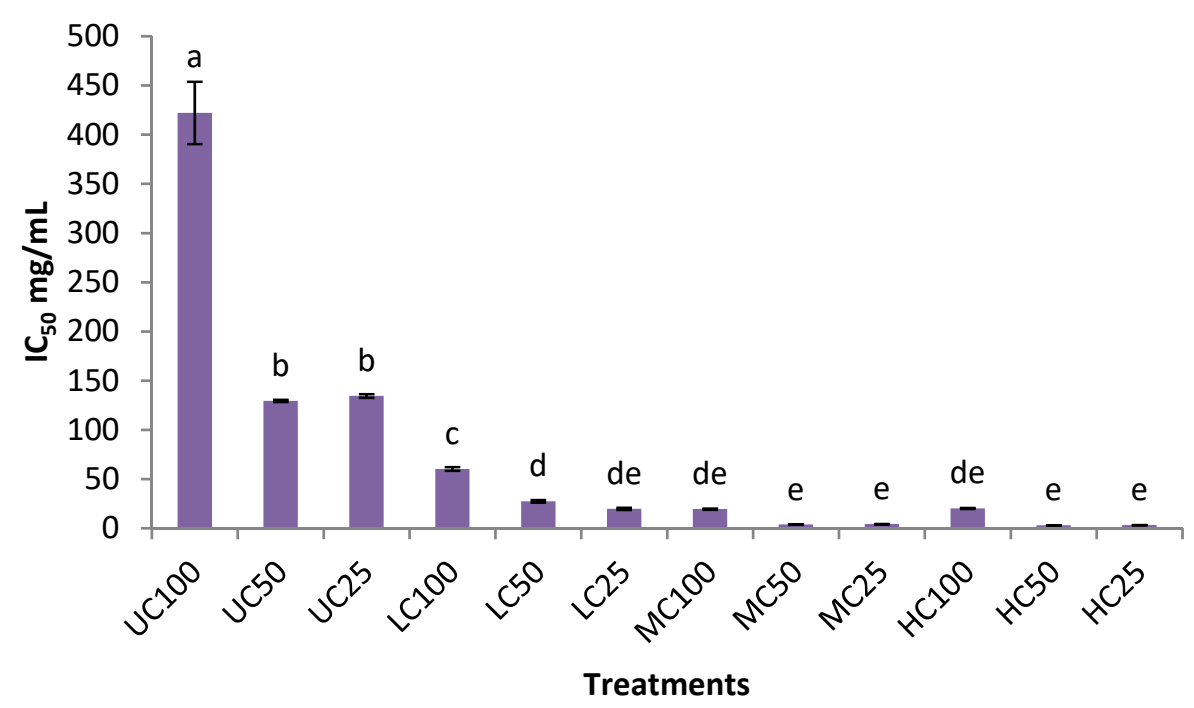

Figure 4. DPPH scavenging of air-fried eggplant. The treatment codes consisting of different letters and digits represent the uncooked (UC), high-cooked (HC), medium-cooked (MC), and low-cooked (LC) eggplant samples extracted with absolute ethanol (100), 50\% ethanol (50), and 25\% ethanol (25). The bars containing different letters are significantly different from each other $(p<0.05)$.

\subsection{Effect of Air-Frying and Extraction Solvents on the Reducing Power of Eggplant}

The reducing power of eggplant as affected by air-frying and extractions solvent is shown in Figure 5. The reducing power of the eggplant was significantly affected by both the air-frying and extraction solvents. The highest reducing power was exhibited by HC50, the high-cooked sample extracted with $50 \%$ ethanol (1.936), followed by HC25, the highcooked eggplant extracted with 50\% ethanol (1.868). Though the medium- and light-cooked samples extracted with 25\% ethanol, MC25 (1.795) and LC25 (1.795), respectively, showed similar reducing power to each other, these were significantly different $(p>0.05)$ from all of the other samples. In general, while the $100 \%$ ethanol extract of eggplant showed the lowest reducing power, the $50 \%$ ethanol extract gave the highest activity. On the other hand, the uncooked samples exhibited the lowest activity, while the high-cooked samples showed the highest reducing power among all of the samples. These findings somewhat echoed the results of TPC and TFC, which showed that the reducing power of the eggplant was to some extent the function of its bioactive compounds. Our results are in accordance with a recent study that demonstrated that the antioxidant activity of eggplant was increased by cooking, with grilled samples showing the highest activity among fresh and baked eggplant [42]. Other previous studies also reported similar findings where the antioxidant activity of the eggplant fruits was increased by thermal treatment [14,34]. 


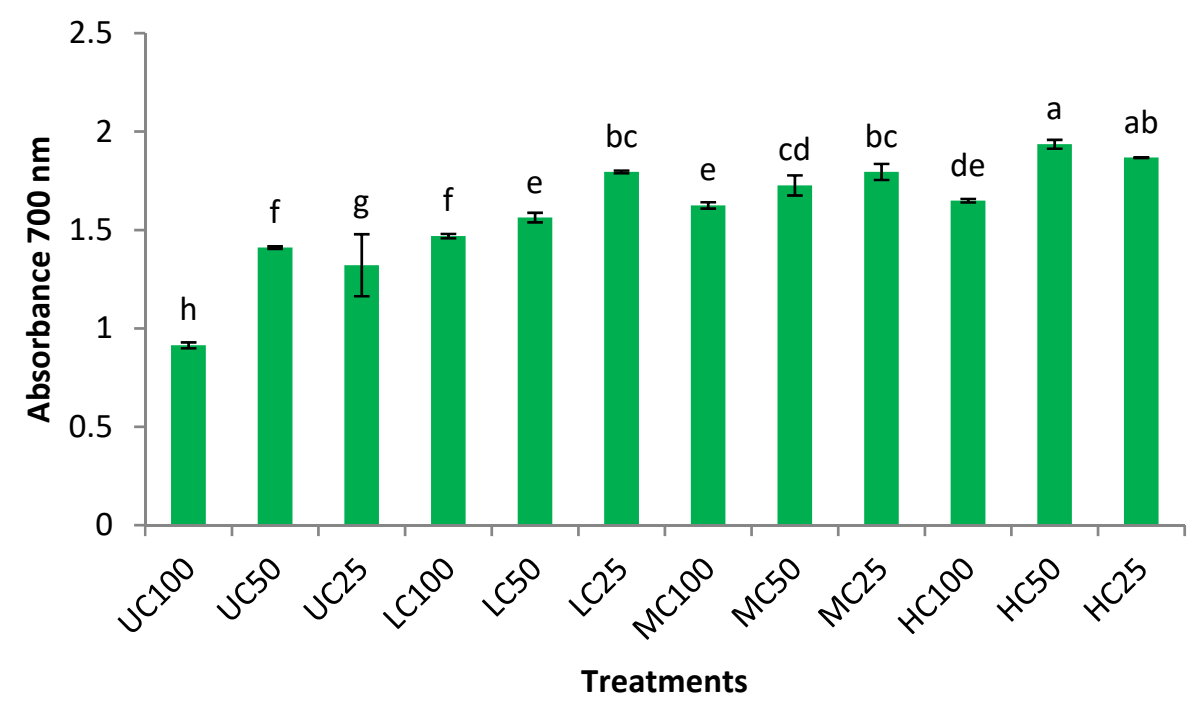

Figure 5. Reducing power of air-fried eggplant. The treatment codes consisting of different letters and digits represent the uncooked (UC), high-cooked (HC), medium-cooked (MC), and low-cooked (LC) eggplant samples extracted with absolute ethanol (100), 50\% ethanol (50), and 25\% ethanol (25). The bars containing different letters are significantly different from each other $(p<0.05)$.

\subsection{Correlation among Total Phenols, Total Flavonoids, and the Antioxidant Activities of Eggplant}

Table 2 shows the correlation among total polyphenol content, total flavonoid content, and the antioxidant assays. The lowest $\mathrm{IC}_{50}$ for DPPH reveals the highest antioxidant activity of the sample. So, for DPPH, a negative correlation would mean the contribution of TPC or TFC towards the antioxidant activity. The results showed that the TPC and TFC had significant correlation $\left(R^{2}>0.698\right)$ with the reducing power of the eggplant sample, while they did not contribute much to the DPPH scavenging, as the correlation coefficients were relatively low.

Table 2. Correlation coefficients among total polyphenols, total flavonoids, and antioxidant activities of the eggplant.

\begin{tabular}{ccc}
\hline & Reducing Power & DPPH Scavenging $\left(\right.$ IC $\left._{\mathbf{5 0}}\right)$ \\
\hline Total polyphenol content & 0.723 & -0.471 \\
\hline Total flavonoid content & 0.698 & -0.460 \\
\hline
\end{tabular}

\subsection{HPLC Analysis of Phenolic Compounds}

The average quantitative phenolic constituents found in eggplant samples are reported in Table 3 and respective chromatograms of standards and air-fried sample are given in Figure 6a,b, respectively. Uncooked (raw) eggplant sample had the lowest concentration of the phenolic compounds $(13.86 \mathrm{mg} / 100 \mathrm{~g})$ as compared to the air-fried eggplant samples. Medium-cooked samples had the highest phenolic compounds (335.5 mg/100 g) compared to high-cooked $(216.15 \mathrm{mg} / 100 \mathrm{~g})$ and light-cooked $(26.92 \mathrm{mg} / 100 \mathrm{~g})$ samples. Tannic acid was the main phenolic compound in all samples of eggplant followed by chlorogenic acid (Table 3). Tannic acid is the hydrolysable tannins present abundantly in parts of the fruit [43]. Alkurd et al. [44] obtained $413.7 \mathrm{mg}$ tannic acid equivalents $/ 100 \mathrm{~g}$ from whole eggplant extract. 
Table 3. Concentration of phenolic compounds in air-fried eggplant (mg/100 g dry weight); ND: not detected.

\begin{tabular}{ccccc}
\hline Compound Name & UC & LC & MC & HC \\
\hline Tannic acid & 8.67 & 14.64 & 283.29 & 138.39 \\
\hline Resorcinol & 0.09 & 0.15 & ND & ND \\
\hline Chlorogenic acid & 4.79 & 12.13 & 48.93 & 77.04 \\
\hline Caffeic acid & 0.21 & ND & 2.77 & 0.57 \\
\hline Vanillin & 0.08 & ND & 0.54 & 0.15 \\
\hline Acetyl salicylic acid & ND & ND & ND & ND \\
\hline
\end{tabular}

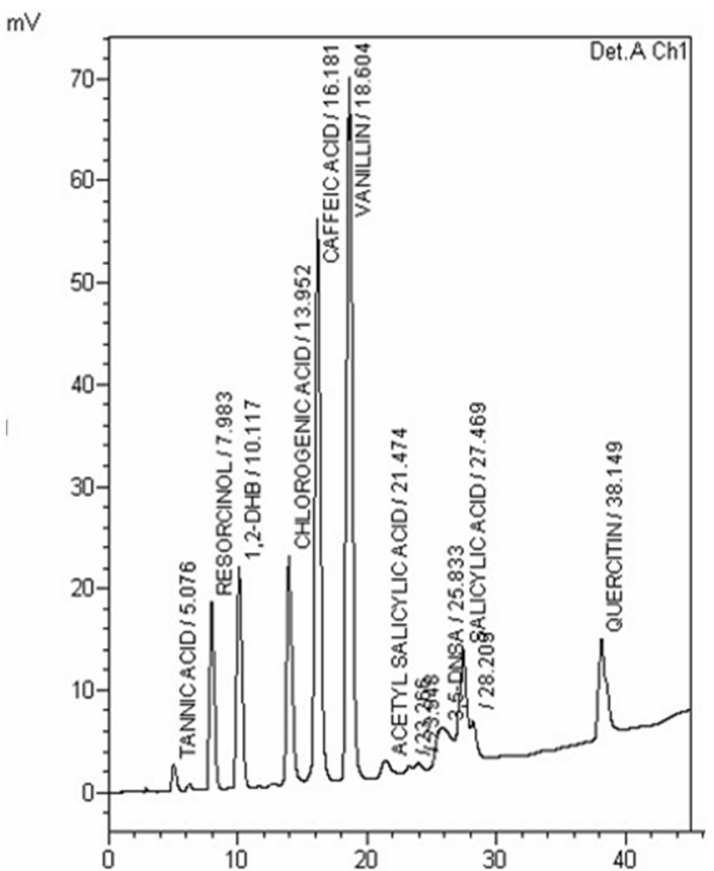

(a)

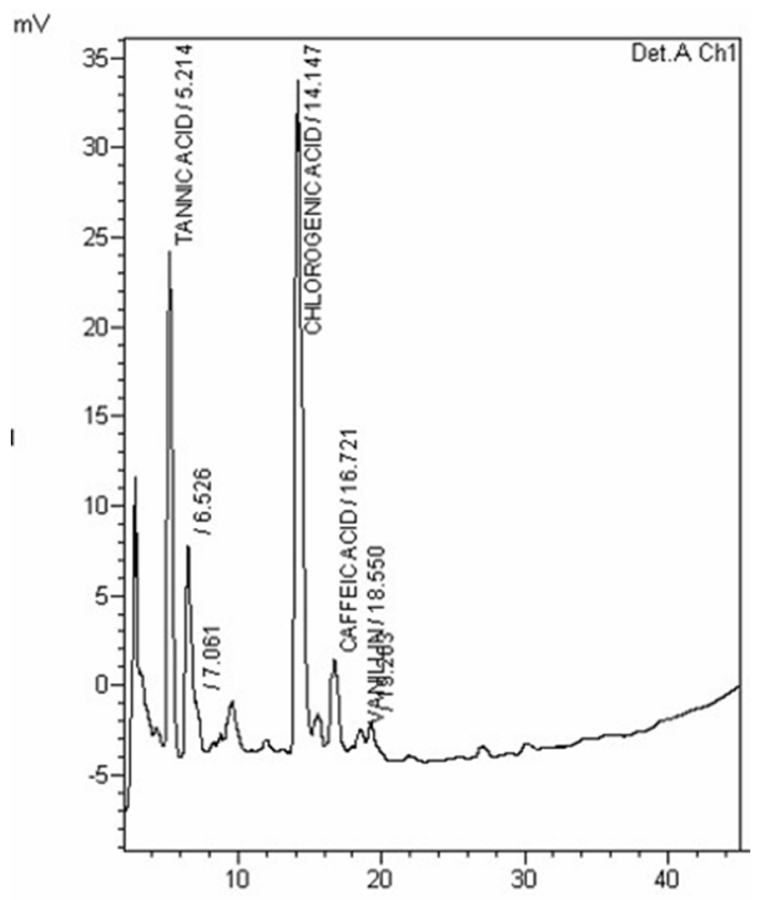

(b)

Figure 6. HPLC chromatograms: (a) standard compounds; (b) high-cooked eggplant extracted with $100 \%$ ethanol.

Chlorogenic acid is the second major phenolic compound found in the eggplant samples. High-cooked samples had the highest chlorogenic acid content $(77.04 \mathrm{mg} / 100 \mathrm{~g})$, followed by medium-cooked sample $(48.93 \mathrm{mg} / 100 \mathrm{~g})$ and then low-cooked samples $(12.13 \mathrm{mg} / 100 \mathrm{~g})$.

\section{Conclusions}

The effect of air-frying along with extraction solvents on the bioactive properties of eggplant was investigated in this study. Both factors showed a promising effect, and the eggplant sample air-fried for a longer time $(25 \mathrm{~min})$ showed better results as compared to the other samples, while the $50 \%$ ethanol was found to be a better extraction solvent. Medium-cooked samples had the highest phenolic compounds ( $335.5 \mathrm{mg} / 100 \mathrm{~g}$ ) compared to high-cooked and low-cooked eggplant. The uncooked sample exhibited the lowest DPPH scavenging and reducing power, while the highest DPPH scavenging activity was recorded for the sample air-fried for $25 \mathrm{~min}$ and extracted with 50\% ethanol. Moreover, the uncooked eggplant sample had the lowest concentration of the phenolic compounds as compared to the air-fried eggplant samples. The tannic acid content was the highest in the medium-cooked sample, whereas the chlorogenic acid content was found to be the highest 
in the high-cooked sample. The results of this study could be helpful for the processing of eggplant.

Author Contributions: Conceptualization, A.M.S. and K.H.; methodology, A.M.S., M.A.A. and K.H.; software, K.H.; validation, M.S.A., N.S.A. and A.M.A.-D.; formal analysis, N.S.A., K.H. and M.A.A.; investigation, A.M.S., S.A. and L.N.A.-H.; resources, A.M.S.; data curation, K.H. and L.N.A.-H.; writing—original draft preparation, K.H. and A.M.S.; writing—review and editing, S.A., A.M.A.-D. and M.A.A.; visualization, K.H. and S.A.; supervision, A.M.S. and K.H.; project administration, M.S.A. and M.A.A.; funding acquisition, A.M.S. All authors have read and agreed to the published version of the manuscript.

Funding: This work received no external funding.

Data Availability Statement: Not applicable.

Acknowledgments: The authors extend their appreciation to the Deanship of Scientific Research at King Saud University for funding this work through research group no (RG-1441-360).

Conflicts of Interest: There is no conflict of interest for this study.

\section{References}

1. Taher, D.; Solberg, S.O.; Prohens, J.; Chou, Y.; Rakha, M.; Wu, T. World vegetable center eggplant collection: Origin, composition, seed dissemination and utilization in breeding. Front. Plant Sci. 2017, 8, 1484-1495. [CrossRef] [PubMed]

2. FAOSTAT. Food and Agriculture Organization of the United Nations. Available online: http://www.fao.org/faostat/en/\#data/ QC (accessed on 3 November 2020).

3. Docimo, T.; Francese, G.; Ruggiero, A.; Batelli, G.; De Palma, M.; Bassolino, L.; Toppino, L.; Rotino, G.L.; Mennella, G.; Tucci, M. Phenylpropanoids accumulation in eggplant fruit: Characterization of biosynthetic genes and regulation by a MYB transcription factor. Front. Plant Sci. 2016, 6, 1233-1251. [CrossRef] [PubMed]

4. Jung, E.J.; Bae, M.S.; Jo, E.K.; Jo, Y.H.; Lee, S.C. Antioxidant activity of different parts of eggplant. J. Med. Plant Res. 2011, 5, 4610-4615.

5. Akanitapichat, P.; Phraibung, K.; Nuchklang, K.; Prompitakkul, S. Antioxidant and hepatoprotective activities of 5 eggplant varieties. Food Chem. Toxicol. 2010, 48, 3017-3021. [CrossRef]

6. Stommel, J.R.; Whitaker, B.D.; Haynes, K.G.; Prohens, J. Genotype $\times$ environment interactions in eggplant for fruit phenolic acid content. Euphytica 2015, 205, 823-836. [CrossRef]

7. Singh, A.P.; Luthria, D.; Wilson, T.; Vorsa, N.; Singh, V.; Banuelos, G.S.; Pasakdee, S. Polyphenols content and antioxidant capacity of eggplant pulp. Food Chem. 2009, 114, 955-961. [CrossRef]

8. Mennella, G.; Lo Scalzo, R.; Fibiani, M.; D’Alessandro, A.; Francese, G.; Toppino, L.; Acciarri, N.; de Almeida, A.E.; Rotino, G.L. Chemical and bioactive quality traits during fruit ripening in eggplant (S. melongena L.) and allied species. J. Agric. Food Chem. 2012, 60, 11821-11831. [CrossRef] [PubMed]

9. Williams, D.J; Edwards, D.; Hamernig, I.; Jian, L.; James, A.P.; Johnson, S.K.; Tapsell, L.C. Vegetables containing phytochemicals with potential anti-obesity properties: A review. Food Res. Int. 2013, 52, 323-333. [CrossRef]

10. Liu, R.H. Whole grain phytochemicals and health. J. Cereal Sci. 2007, 46, 207-219. [CrossRef]

11. Nayak, B.; Rui, H.L.; Tang, J. Effect of processing on phenolic antioxidants of fruits, vegetables, and grains-a review. Crit. Rev. Food Sci. Nutr. 2015, 55, 887-919. [CrossRef]

12. Ferreira, S.F.; Sampaio, G.R.; Keller, L.M.; Sawaya, A.C.H.F.; Ch 'avez, D.W.H.; Torres, E.A.F.S.; Saldanha, T. Impact of air Frying on cholesterol and fatty acids oxidation in sardines: Protective effects of aromatic herbs. J. Food Sci. 2017, 82, 2823-2831. [CrossRef]

13. Donado-Pestana, C.M.; Salgado, J.M.; Rios, A.O.; Santos, P.R.; Jablonski, A. Stability of carotenoids, total phenolics and in vitro antioxidant capacity in the thermal processing of orange-fleshed sweet potato (Ipomoea batatas Lam.) cultivars grown in Brazil. Plant Foods Hum. Nutr. 2012, 67, 262-270. [CrossRef] [PubMed]

14. Arkoub-Djermoune, L.; Boulekbache-Makhlouf, L.; Zeghichi-Hamri, S.; Bellili, S.; Boukhalfa, F.; Madani, K. Influence of the thermal processing on the physicochemical properties and the antioxidant activity of a solanaceae vegetable: Eggplant. J. Food Qual. 2016, 39, 181-191. [CrossRef]

15. Faller, A.L.K.; Fialho, E. The antioxidant capacity and polyphenol content of organic and conventional retail vegetables after domestic cooking. Food Res. Int. 2009, 42, 210-215. [CrossRef]

16. Miglio, C.; Chiavaro, E.; Visconti, A.; Fogliano, V.; Pellegrini, N. Effects of different cooking methods on nutritional and physicochemical characteristics of selected vegetables. J. Agric. Food Chem. 2008, 56, 139-147. [CrossRef] [PubMed]

17. Gürbüz, N.; Uluişik, S.; Frary, A.; Frary, A.; Doğanlar, S. Health benefits and bioactive compounds of eggplant. Food Chem. 2018, 268, 602-610. [CrossRef]

18. Naeem, M.Y.; Ugur, S. Nutritional content and health benefits of eggplant. Turk. J. Agric.- Food Sci. Technol. 2019, 7, 31-36.

19. Krokida, M.K.; Oreopolou, V.; Maroulis, Z.B. Water loss and oil uptake as a function of frying time. J. Food Eng. 2000, 44, 39-46. [CrossRef] 
20. Moreira, R.G.; Sun, X.; Chen, Y. Factors affecting oil uptake in tortilla chips in deep-fat frying. J. Food Eng. 1997, 31, 485-498. [CrossRef]

21. Sun, Y.; Liu, B.; Snetselaar, L.G.; Robinson, J.G.; Wallace, R.B.; Peterson, L.L.; Bao, W. Association of fried food consumption with all cause, cardiovascular, and cancer mortality: Prospective cohort study. BMJ 2019, 364, 5420-5429. [CrossRef]

22. Payab, M.; Kelishadi, R.; Qorbani, M.; Motlagh, M.E.; Ranjbar, S.H.; Ardalan, G.; Zahedi, H.; Chinian, M.; Asayesh, H.; Larijani, B.; et al. Association of junk food consumption with high blood pressure and obesity in Iranian children and adolescents: The CASPIAN-IV Study. J. Pediatr. (Rio J) 2015, 91, 196-205. [CrossRef]

23. Shaker, M. Air Frying a New Technique for Produce of Healthy Fried Potato Strips. J. Food Nutr. Sci. 2014, 2, $200-2006$.

24. Joshy, C.G.; Ratheesh, G.; Ninan, G.; Kumar, K.A.; Ravishankar, C.N. Optimizing air-frying process conditions for the development of healthy fish snack using response surface methodology under correlated observations. J. Food Sci. Technol. 2020, 57, 2651-2658. [CrossRef] [PubMed]

25. Hayat, K. Impact of drying methods on the functional properties of peppermint (Mentha piperita L.) leaves. Sci. Lett. 2020, 8, 36-42.

26. Aoshima, H.; Tsunoue, H.; Koda, H.; Kiso, Y. Aging of whiskey increases 1, 1-diphenyl-2-picrylhydrazyl radical scavenging activity. J. Agric. Food Chem. 2004, 52, 5240-5244. [CrossRef] [PubMed]

27. Sharma, S.; Vig, A.P. Evaluation of in vitro antioxidant properties of methanol and aqueous extracts of Parkinsonia aculeata L. Leaves. Sci. World J. 2013, 604865, 1-7.

28. He, J.; Yin, T.; Chen, Y.; Cai, L.; Tai, Z.; Li, Z.; Liu, C.; Wang, Y.; Ding, Z. Phenolic 374 compounds and antioxidant activities of edible flowers of Pyrus pashia. J. Funct. 2015, 17, 371-379. [CrossRef]

29. Król, K.; Gantner, M.; Tatarak, A.; Hallmann, E. The content of polyphenols in coffee beans as roasting, origin and storage effect. Eur. Food Res. Technol. 2020, 246, 33-39. [CrossRef]

30. Diviš, P.; Pořízka, J.; Kř́kala, J. The effect of coffee beans roasting on its chemical composition. Potravinarstvo Slovak J. Food Sci. 2019, 13, 344-350. [CrossRef]

31. Das, S.; Raychaudhuri, U.; Falchi, M.; Bertelli, C.A.; Bragac, P.C.; Das, D.K. Cardioprotective properties of raw and cooked eggplant (Solanum melongena L). Food Funct. 2011, 2, 395-399. [CrossRef]

32. Lo Scalzo, R.; Fibiani, M.; Mennella, G.; Rotino, G.L.; Dal Sasso, M.; Culici, M.; Spallino, A.; Braga, P.C. Thermal treatment of eggplant (Solanum melongena L.) increases the antioxidant content and the inhibitory effect on human neutrophil burst. J. Agric. and Food Chem. 2010, 58, 3371-3379. [CrossRef]

33. Ramírez-Anaya, J.D.P.; Samaniego-Sánchez, C.; Castañeda-Saucedo, M.C.; Villalón-Mir, M.; de la Serrana, H.L.-G. Phenols and the antioxidant capacity of Mediterranean vegetables prepared with extra virgin olive oil using different domestic cooking techniques. Food Chem. 2015, 188, 430-438. [CrossRef] [PubMed]

34. Zambrano-Moreno, E.L.; Chávez-Jáuregui, R.N.; Plaza, M.D.L.; Wessel-Beaver, L. Phenolic content and antioxidant capacity in organically and conventionally grown eggplant (Solanum melongena) fruits following thermal processing. Food Sci. Technol. Campinas. 2015, 5, 414-420. [CrossRef]

35. Pekič, B.; Kovač, V.; Alonso, E.; Revilla, E. Study of the extraction of proanthocyanidins from grape seeds. Food Chem. 1998, 61, 201-206. [CrossRef]

36. Yilmaz, Y.; Toledo, R.T. Oxygen radical absorbance capacities of grape/wine industry byproducts and effect of solvent type on extraction of grape seed polyphenols. J. Food Compos. Anal. 2006, 19, 41-44. [CrossRef]

37. Biscaia, D.; Ferreira, S.R.S. Propolis extracts obtained by low-pressure methods and supercritical fluid extraction. J. Supercrit. Fluids 2009, 51, 17-23. [CrossRef]

38. Chumyam, A.; Whangchai, K.; Jungklang, J.; Faiyue, B.; Saengnil, K. Effects of heat treatments on antioxidant capacity and total phenolic content of four cultivars of purple skin eggplants. Sci. Asia 2013, 39, 246-251. [CrossRef]

39. Uthumporn, U.; Laila, D.L.; Rabeta, M.S.; Aida, H.; Ruri, A.S. Effects of different cooking methods on the physico-chemical and quality attributes of eggplants. Int. J. Adv. Sci. Eng. Inf. Technol. 2016, 6, 460-464.

40. Juániz, I.; Ludwig, I.A.; Huarte, E.; Pereira-Caro, G.; Moreno-Rojas, J.M.; Cid, C.; De Peña, M.P. Influence of heat treatment on antioxidant capacity and (poly)phenolic compounds of selected vegetables. Food Chem. 2016, 197, 466-473. [CrossRef]

41. Nicoli, M.C.; Anese, M.; Parpinel, M. Influence of processing on the antioxidant properties of fruit and vegetables. Trends Food Sci. Technol. 1999, 10, 94-100. [CrossRef]

42. Šilarová, P.; Boulekbache-Makhlouf, L.; Pellati, F.; Česlová, L. Monitoring of chlorogenic acid and antioxidant capacity of Solanum melongena L. (eggplant) under different heat and storage treatments. Antioxidants (Basel) 2019, 8, 234.

43. Chung, K.-T.; Wong, T.Y.; Wei, C.-I.; Huang, Y.-W.; Lin, Y. Tannins and human health: A review. Crit. Rev. Food Sci. Nutr. 1998, 38, 421-464.

44. Alkurd, A.; Takruri, H.R.; Al-Sayyed, H. Tannin contents of selected plants used in Jordan. Jordan J. Agric. Sci. 2008, 4, 265-274. 